\title{
Time Evolution Characterization of Atmospheric-Pressure Plasma Jet (APPJ)-Synthesized $\mathrm{Pt}_{-\mathrm{SnO}}$ Catalysts
}

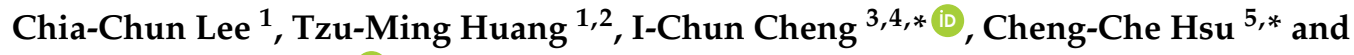 \\ Jian-Zhang Chen ${ }^{1,2, *(1)}$ \\ 1 Graduate Institute of Applied Mechanics, National Taiwan University, Taipei 10617, Taiwan; \\ r05543015@ntu.edu.tw (C.-C.L.); r06543009@ntu.edu.tw (T.-M.H.) \\ 2 Advanced Research Center for Green Materials Science and Technology, National Taiwan University, \\ Taipei 10617, Taiwan \\ 3 Graduate Institute of Photonics and Optoelectronics, National Taiwan University, Taipei 10617, Taiwan \\ 4 Department of Electrical Engineering, National Taiwan University, Taipei 10617, Taiwan \\ 5 Department of Chemical Engineering, National Taiwan University, Taipei 10617, Taiwan \\ * Correspondence: iccheng@ntu.edu.tw (I.-C.C.); chsu@ntu.edu.tw (C.-C.H.); jchen@ntu.edu.tw (J.-Z.C.); \\ Tel.: +886-2-33669648 (I.-C.C.); +886-2-33663034 (C.-C.H.); +886-2-33665694 (J.-Z.C.)
}

Received: 17 August 2018; Accepted: 29 August 2018; Published: 1 September 2018

\begin{abstract}
We characterize the time evolution $(\leq 120$ s) of atmospheric-pressure plasma jet (APPJ)-synthesized Pt-SnO $x$ catalysts. A mixture precursor solution consisting of chloroplatinic acid and tin(II) chloride is spin-coated on fluorine-doped tin oxide (FTO) glass substrates, following which APPJ is used for converting the spin-coated precursors. X-ray photoelectron spectroscopy (XPS) indicates the conversion of a large portion of metallic $\mathrm{Pt}$ and a small portion of metallic $\mathrm{Sn}$ (most $\mathrm{Sn}$ is in oxidation states) from the precursors with $120 \mathrm{~s}$ APPJ processing. The dye-sensitized solar cell (DSSC) efficiency with APPJ-synthesized Pt-SnO $x$ CEs is improved greatly with only $5 \mathrm{~s}$ of APPJ processing. Electrochemical impedance spectroscopy (EIS) and Tafel experiments confirm the catalytic activities of $\mathrm{Pt}-\mathrm{SnO}_{x}$ catalysts. The DSSC performance can be improved with a short APPJ processing time, suggesting that a DC-pulse nitrogen APPJ can be an efficient tool for rapidly synthesizing catalytic $\mathrm{Pt}_{-} \mathrm{SnO}_{x}$ counter electrodes (CEs) for DSSCs.
\end{abstract}

Keywords: atmospheric pressure plasma jet; platinum; tin oxide; dye-sensitized solar cells; chloroplatinic acid; tin chloride

\section{Introduction}

Atmospheric-pressure plasma (APP) technology is operated without using a vacuum chamber and associated pumping system. It is therefore considered a cost-effective manufacturing tool. Recent developments have resolved stability and arcing problems, making APP technology promising for industrial applications. Traditional APP sources include transferred arc, corona discharge, dielectric barrier discharge, and atmospheric pressure plasma jet (APPJs) [1,2]. APPs with various heavy particle temperatures and charge densities can be produced by using different excitation methods and electrode configuration designs. The synergy between the reactive plasma species and heat can promote rapid chemical reactions during material processing [3-6]. APPs have been used for processing various types of materials, such as carbon nanotubes [3,7,8] and reduced graphene oxides [9-11]. Applications of APPs for surface cleaning or modification [12-14], deposition of metal oxides [15,16], and syntheses of metal compounds from liquid precursors $[6,17,18]$ have been extensively investigated. 
Metals and metal oxides are common catalysts [19-24]. APPs also have been used for syntheses and post-treatments of catalysts [25].

In 1991, Grätzel et al. reported a great breakthrough of DSSCs [26], and since then, dye-sensitized solar cells (DSSCs) have been extensively investigated. A conventional DSSC consists of a dye-adsorbed photoanode, an electrolyte, and a counter electrode (CE). A catalytic $\mathrm{CE}$ is used for reducing triiodide into iodine in the electrolyte. Generally, Pt is the most commonly used CE material in DSSC, owing to its high catalytic activity and stability [27]. Various alternative CE materials such as carbon-based materials, metal oxides or chalcogenides, and alloys or intermetallics have been studied extensively [3,5,28-36]. Composites containing Pt and Sn have been used as electrocatalysts for CEs of DSSCs [36,37], methanol or ethanol oxidation [38-44], aqueous phase oxidation [45], and gas sensing [46]. The addition of metal oxides has been reported to improve the catalytic activity [40,47]. Pt:SnO ${ }_{2}$ electrocatalytic films were used as CEs of DSSCs [48]. Dao et al. fabricated DSSCs with a $\mathrm{PtSn}$ alloy supported by reduced graphene oxides via dry plasma reduction [36]. In the present study, $\mathrm{Pt}-\mathrm{SnO}_{x}$ composites were synthesized by mixing chloroplatinic acid and tin(II) chloride that were processed using a DC-pulse nitrogen APPJ. X-ray photoelectron spectroscopy (XPS) results showed that the majority of Sn was in the oxidation state. The DSSC efficiency can be improved rapidly through $5 \mathrm{~s}$ APPJ processing of the chloroplatinic acid and tin(II) chloride mixture precursor; no metallic $\mathrm{Pt}$ was converted within such a short processing time. This suggests the catalytic effect of oxidized $\mathrm{Pt}$ and $\mathrm{Sn}$ compounds. A DSSC with a $120 \mathrm{~s}$ APPJ-processed $\mathrm{Pt}_{-} \mathrm{SnO} \mathrm{C}_{x} \mathrm{CE}$ shows efficiency comparable to that of a cell with a furnace-processed Pt CE.

\section{Materials and Methods}

\subsection{Preparation of $\mathrm{Pt}-\mathrm{Sn} \mathrm{O}_{x} \mathrm{CES}$}

25-mM chloroplatinic acid $\left(\mathrm{H}_{2} \mathrm{PtCl}_{6}\right)$ (purity: 99.95\%, Uniregion Biotech, Taipei, Taiwan) and $25-\mathrm{mM}$ tin(II) chloride $\left(\mathrm{SnCl}_{2}\right)$ isopropanol solutions were separately stirred for $24 \mathrm{~h}$. These two solutions were mixed with the same volume ratios and were stirred using a magnetic stirrer (PC-420D, Corning Inc., Corning, NY, USA)for another $24 \mathrm{~h}$. Next, $60 \mu \mathrm{L}$ of the mixture precursor was spin-coated onto fluorine-doped tin oxide (FTO) substrates with an area of $1.5 \mathrm{~cm} \times 1.5 \mathrm{~cm}$ at a speed of $1000 \mathrm{rpm}$ for $15 \mathrm{~s}$. The spin-coated precursors were then processed by a nitrogen APPJ for 5, 15, 30, 60, and $120 \mathrm{~s}$. Figure 1a shows the APPJ setup. The operation parameters are as follows: nitrogen flow of 46 standard liter per minute (slm), power supply voltage of $275 \mathrm{~V}$, and ON/OFF duty cycle of 7/33 $\mu$ s. The temperature evolution of the substrates, shown in Figure 1b, was measured using a K-type thermocouple (OMEGA Engineering, Norwalk, CT, USA). The temperature rapidly increased to $\sim 510^{\circ} \mathrm{C}$, and it dramatically decreased after the APPJ was turned off. Because our process is conducted at $\sim 510{ }^{\circ} \mathrm{C}$, we use FTO glass substrates (Sigma-Aldrich, St. Louis, MO, USA) which can tolerate a higher processing temperature.

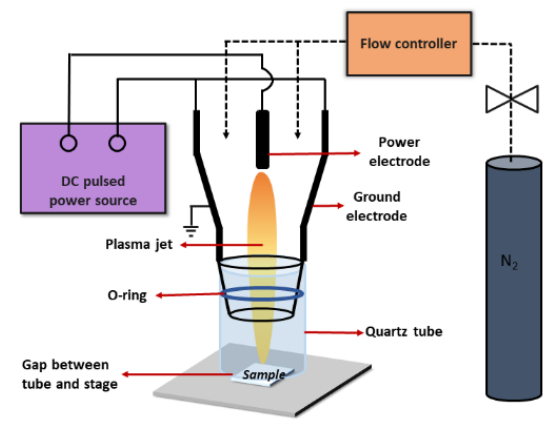

(a)

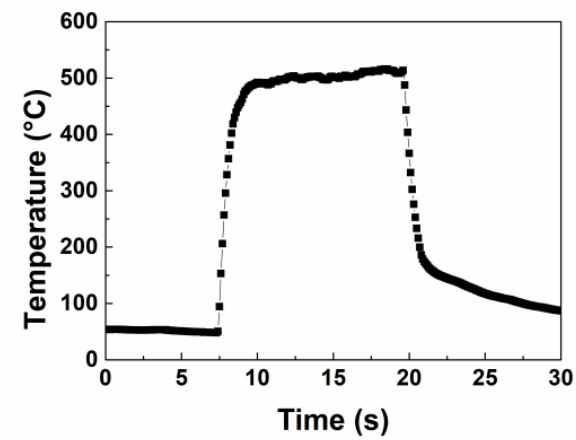

(b)

Figure 1. (a) Schematic of APPJ setup; (b) Temperature evolution of substrate during APPJ treatment. 


\subsection{Preparation of $\mathrm{TiO}_{2}$ Photoanode and Assembly of DSSCs}

The photoanode consists of a $\mathrm{TiO}_{2}$ compact layer and a $\mathrm{TiO}_{2}$ nanoporous layer for dye adsorption. First, a 0.23-M titanium isopropoxide solution (Fluka, St. Louis, MO, USA) was spin-coated on a FTO substrate and then baked at $200{ }^{\circ} \mathrm{C}$ for $10 \mathrm{~min}$ to form a $\mathrm{TiO}_{2}$ compact layer to prevent electron recombination. Then, $1.6 \mathrm{~g}$ of $\mathrm{TiO}_{2}$ nanoparticles (diameter: $\sim 21 \mathrm{~nm}$ ), $8 \mathrm{~mL}$ of ethanol, $6.49 \mathrm{~g}$ of terpineol (anhydrous, \#86480, Fluka, St. Louis, MO, USA), $4.5 \mathrm{~g}$ of $10 \mathrm{wt} \%$ ethyl cellulose ethanolic solution (5-15 mPa.s, \#46070, Fluka, St. Louis, MO, USA), and $3.5 \mathrm{~g}$ of $10 \mathrm{wt} \%$ ethyl cellulose ethanolic solution (30-50 mPa.s, \#46080, Fluka, St. Louis, MO, USA) were mixed together. Next, a $0.4 \mathrm{~g}$ mixture containing $\mathrm{TiO}_{2}$ was mixed with $500 \mu \mathrm{L}$ of ethanol and stirred using a magnetic stirrer for $24 \mathrm{~h}$. The mixed solution was baked at $53{ }^{\circ} \mathrm{C}$ until its weight became $0.175 \mathrm{~g}$, thus completing the preparation of the $\mathrm{TiO}_{2}$ pastes. The $\mathrm{TiO}_{2}$ pastes were screen-printed onto the $\mathrm{TiO}_{2}$ compact layer coated FTO substrate with a printed area of $0.5 \mathrm{~cm} \times 0.5 \mathrm{~cm}$. The screen-printed pastes were calcined at $510{ }^{\circ} \mathrm{C}$ for $15 \mathrm{~min}$ in a conventional furnace to form the $\mathrm{TiO}_{2}$ photoanode. Next, the $\mathrm{TiO}_{2}$ photoanode was immersed in a 0.3-mM N719 solution, which is mixed with acetonitrile and tertbutyl alcohol in a 1:1 volume ratio for $24 \mathrm{~h}$. This completed the preparation of the dye-anchored nanoporous $\mathrm{TiO}_{2}$ photoanodes.

The Pt-SnO ${ }_{x}$ CEs and dye-anchored $\mathrm{TiO}_{2}$ photoanodes were assembled with a 25 - $\mu$ m-thick spacer to form sandwich-structure DSSCs. Then, a commercial electrolyte (E-Solar EL 200, Everlight Chemical Industrial Co., Taipei, Taiwan) was injected into the solar cells.

Counterpart DSSC with furnace-processed Pt CE was fabricated for comparison. In this case, $60 \mu \mathrm{L}$ of $25-\mathrm{mM} \mathrm{H}_{2} \mathrm{PtCl}_{6}$ isopropanol solution was spin-coated on the FTO substrate and calcined at $400{ }^{\circ} \mathrm{C}$ for $15 \mathrm{~min}$ using a tube furnace. The assembly procedure of DSSC with furnace-processed Pt $\mathrm{CE}$ is the same as that of DSSC with APPJ-processed Pt-SnO $\mathrm{CE} \mathrm{C}$

\subsection{Characterization of Materials and DSSCs}

During the APPJ reduction processes, a spectrometer (USB4000, Ocean Optics, Largo, FL, USA) was used for monitoring the plasma optical emission spectra (OES). Pt-SnO $\mathrm{P}_{x}$ nanoparticles were inspected using a scanning electron microscope (SEM, JSM-7800F Prime, JEOL, Tokyo, Japan) with an energy-dispersive spectroscopy (EDS) attachment. To investigate the chemical configuration of $\mathrm{Pt}-\mathrm{SnO} \mathrm{O}_{x}$ XPS (Thermo K-Alpha, VGS, Waltham, MA, USA was used for analyzing the binding status. The C1s core level was centered at $284.6 \mathrm{eV}$ to calibrate the binding energy scale. XPSPEAK 4.1 software (was used for fitting binding energy positions. XPS samples were prepared with Corning glass substrates instead of FTO glass ones to avoid the interference of Sn signals emitted from FTO substrates. To examine the electrochemical catalytic activities of $\mathrm{Pt}-\mathrm{SnO} x$ CEs, electrochemical impedance spectroscopy (EIS) and Tafel measurements were performed using an electrochemical workstation (PGSTAT204, Metrohm Autolab, Herisau, Switzerland). EIS measurements were performed with a sinusoidal amplitude of $10 \mathrm{mV}$ with frequencies of $0.1-10^{5} \mathrm{~Hz}$, and the data were fitted using Z-view 3.1 software. Tafel curves were recorded from $-0.6 \mathrm{~V}$ to $0.6 \mathrm{~V}$ at a scan rate of $50 \mathrm{mV} / \mathrm{s}$. Both measurements were performed on a symmetrical cell with two equal Pt-SnO $\mathrm{CES}_{x}$. A solar simulator (WXS-155S-L2, WACOM, Saitama, Japan) with an AM 1.5 filter equipped with an electrometer (Keithley 2440, Tektronix, Beaverton, OR, USA) was used for measuring the photocurrent-voltage characteristics of the DSSCs.

\section{Results and Discussion}

Figure 2a shows the plasma OES evolution during APPJ processing of the mixed $\mathrm{H}_{2} \mathrm{PtCl}_{6} / \mathrm{SnCl}_{2}$ precursor. $\mathrm{NO}_{\gamma}, \mathrm{NO}_{\beta}, \mathrm{N}_{2}$ 1st positive, and $\mathrm{N}_{2}$ 2nd positive emissions were observed clearly during $120 \mathrm{~s}$ APPJ processes. Figure $2 \mathrm{~b}$ shows the plasma spectra when processing $\mathrm{H}_{2} \mathrm{PtCl}_{6}, \mathrm{SnCl}_{2}$, and mixed $\mathrm{H}_{2} \mathrm{PtCl}_{6} / \mathrm{SnCl}_{2}$ precursors on the FTO substrates. The $\mathrm{NO}_{\gamma}$ system $\left(\mathrm{A}^{2} \Sigma^{+}-\mathrm{X}^{2} \Pi\right)$ is located at wavelengths lower than $280 \mathrm{~nm}$. The $\mathrm{NO}_{\beta}$ system $\left(\mathrm{B}^{2} \Pi-\mathrm{X}^{2} \Pi\right)$ is located from around 260 to 500 
$\mathrm{nm}$, and it partially overlaps the $\mathrm{NO}_{\gamma}$ system. The other emissions at 357, 385, and 389 nm were attributed to the $N_{2}$ 2nd positive system $\left(C^{3} \Pi_{u}-B^{3} \Pi_{g}\right)$; these overlap with the $\mathrm{NO}_{\beta}$ system. The $N_{2}$ 1st positive system $\left(B^{3} \Pi_{\mathrm{g}}-\mathrm{A}^{3} \Sigma_{\mathrm{u}}{ }^{+}\right)$was located at wavelengths higher than $530 \mathrm{~nm}$.

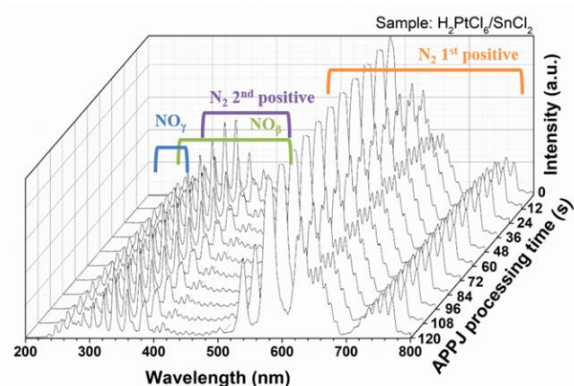

(a)

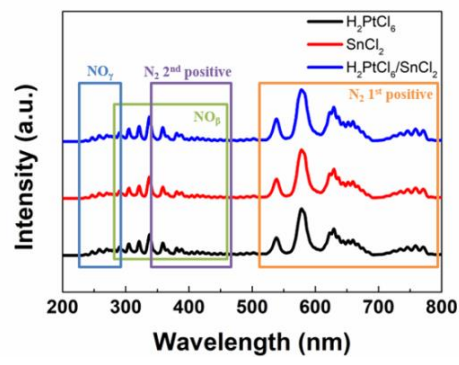

(b)

Figure 2. (a) OES evolution during APPJ processing of mixed $\mathrm{H}_{2} \mathrm{PtCl}_{6} / \mathrm{SnCl}_{2}$ precursors. (b) OES when processing $\mathrm{H}_{2} \mathrm{PtCl}_{6}, \mathrm{SnCl}_{2}$, and mixed $\mathrm{H}_{2} \mathrm{PtCl}_{6} / \mathrm{SnCl}_{2}$ precursors using nitrogen APPJ.

Figure 3a-e shows the SEM images of $\mathrm{Pt}_{-\mathrm{SnO}}$ nanoparticles converted from mixed $\mathrm{H}_{2} \mathrm{PtCl}_{6} / \mathrm{SnCl}_{2}$ precursors on the FTO glass substrates using various APPJ processing times. The nanoparticle size and morphology remained similar for APPJ processing times of 5-120 s. Figure $3 \mathrm{f}$ shows EDS results for the $120 \mathrm{~s}$ and APPJ-processed sample. Pt and Sn signals indicate the presence of two elements in the nanoparticles. Both of $\mathrm{Sn}$ and $\mathrm{O}$ signals could result from the nanoparticles and the FTO substrates.

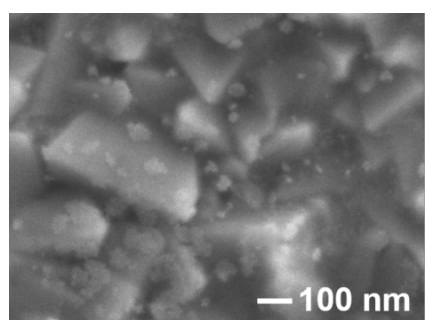

(a)

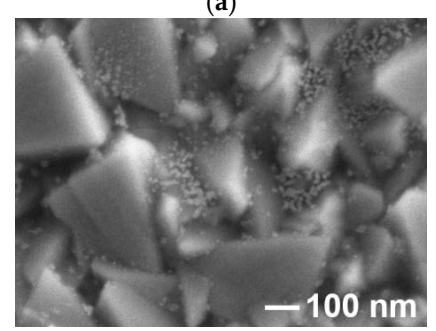

(c)

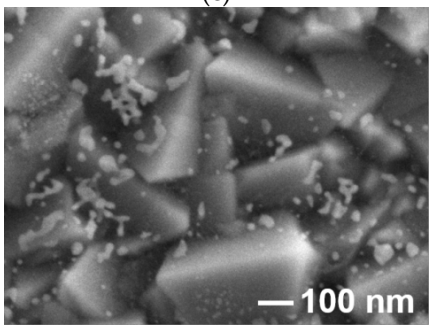

(e)

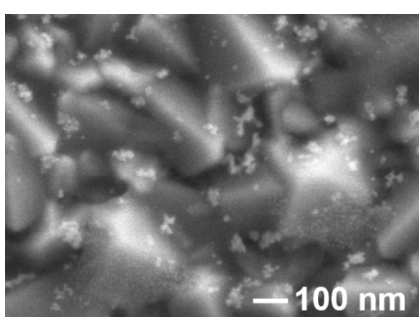

(b)

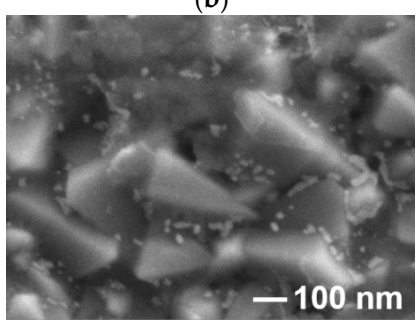

(d)

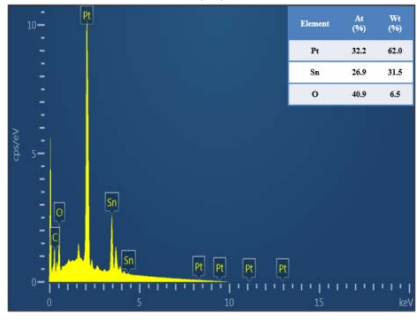

(f)

Figure 3. Scanning electron microscope (SEM) images of samples processed by APPJ for various durations: (a) $5 \mathrm{~s}$, (b) $15 \mathrm{~s}$, (c) $30 \mathrm{~s}$, (d) $60 \mathrm{~s}$, and (e) $120 \mathrm{~s}$. (f) Energy-dispersive spectroscopy (EDS) spectrum of nanoparticles converted from $\mathrm{H}_{2} \mathrm{PtCl}_{6} / \mathrm{SnCl}_{2}$ precursors on FTO glass substrates using 120 s APPJ processing. 
To identify the chemical states of $\mathrm{Pt}_{-} \mathrm{SnO}_{x}$ compounds, Figure 4a,b shows the XPS spectra of $\mathrm{Pt} 4 \mathrm{f}$ and Sn3d for samples. The Pt4f spectrum can be deconvoluted into three components including $\mathrm{Pt}, \mathrm{Pt}^{2+}$, and $\mathrm{Pt}^{4+}$. The metallic peaks of $\mathrm{Pt}$ are located at 71.30 and $74.65 \mathrm{eV}, \mathrm{Pt}(\mathrm{II})$ components are located at 72.70 and $76.50 \mathrm{eV}$, and Pt(IV) components are located at 73.80 and $77.15 \mathrm{eV}$ [49,50]. In Figure $4 \mathrm{a}$, the major peaks belong to $\mathrm{Pt}^{2+}$ and $\mathrm{Pt}^{4+}$ for as-deposited and 5 and $15 \mathrm{~s} \mathrm{APPJ-processed}$ samples. These results indicate that most of the $\mathrm{H}_{2} \mathrm{PtCl}_{6} / \mathrm{SnCl}_{2}$ precursor was not converted to metallic Pt by APPJ processing for less than $15 \mathrm{~s}$. As the APPJ processing time increases, increased conversion of precursors into metallic Pt was clearly observed. The $\mathrm{Pt}^{2+}$ signal is noted as the oxidation state of $\mathrm{Pt}$, and it could indicate $\mathrm{PtO}$ [51,52] or $\mathrm{Pt}(\mathrm{OH})_{2}$ [53]. The presence of Pt oxidation states, due to the interaction with the Pt-support, is attributed to an electronic effect or oxygen absorption from air $[54,55]$. Figure $4 \mathrm{~b}$ shows the oxidation state of Sn3d under various APPJ processing times. The binding energy of Sn3d can be deconvoluted into two categories: one at 485.8 and $494.2 \mathrm{eV}$ for the zero-valent state of Sn, and the other at 487.3 and $495.7 \mathrm{eV}$ for Sn(II/IV) components [56]. The major peak is attributed to the oxidation state of $\mathrm{Sn}$ for up to $120 \mathrm{~s}$, and the percentage of metallic Sn increased only slightly increased with the APPJ processing time. Sn(II) and Sn(IV) species are difficult to distinguish from XPS measurements because of the small difference between their binding energies [57,58]. Tables 1 and 2 show the percentages of $\mathrm{Pt}$ and $\mathrm{Sn}$ species, respectively. The Pt-support interaction may influence charge transfer from Pt to oxygen species on the surface and improve the electrochemical catalytic abilities and catalyst stability [47].
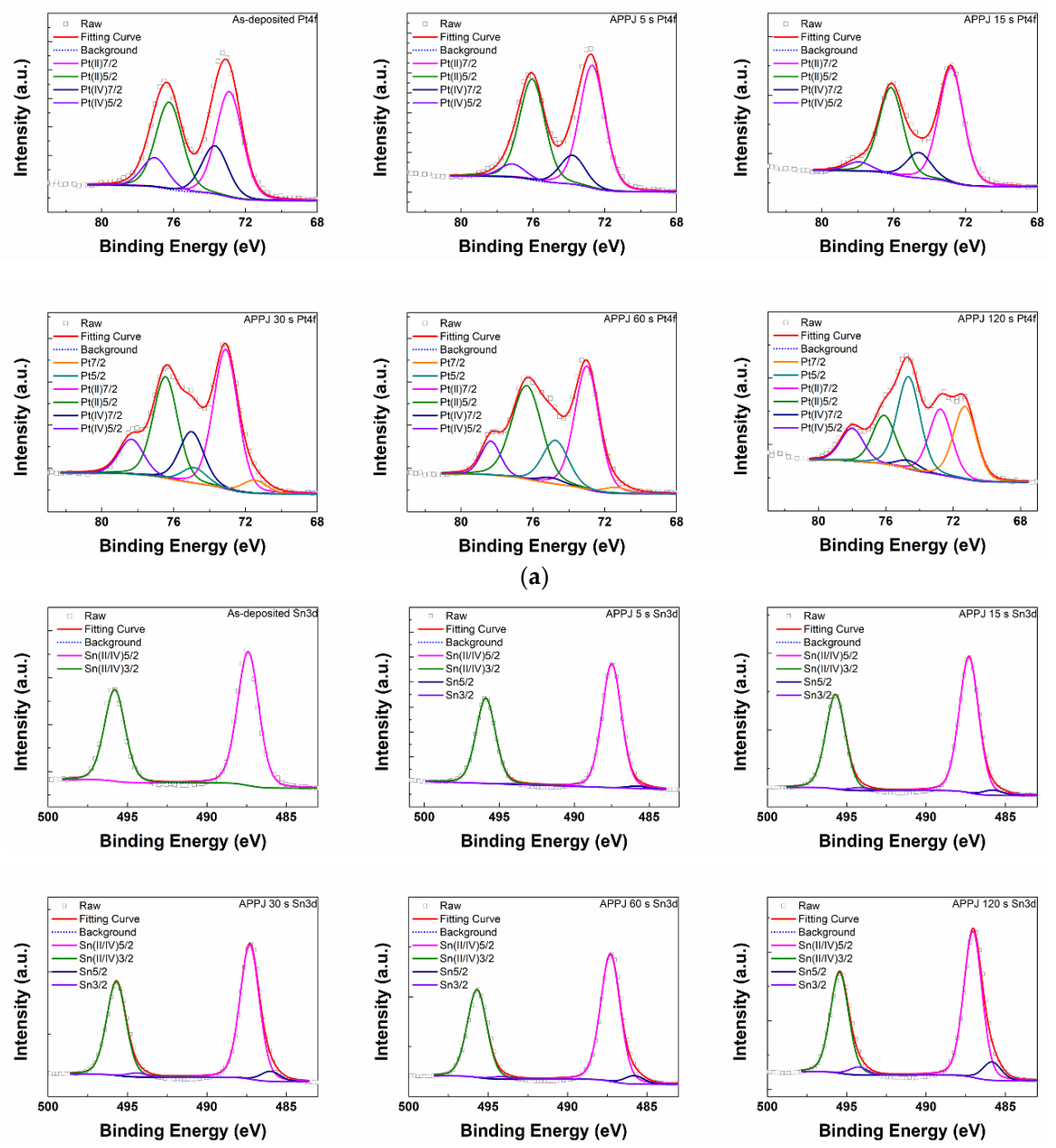

(b)

Figure 4. X-ray photoelectron spectroscopy (XPS) spectra of (a) Pt4f and (b) Sn3d for samples processed by APPJ for various durations. 
Table 1. Percentage of Pt species obtained from XPS analysis.

\begin{tabular}{ccccccc}
\hline APPJ Pt4f (\%) & Pt 7/2 & Pt 5/2 & Pt(II) 7/2 & Pt(II) 5/2 & Pt(IV) 7/2 & Pt(IV) 5/2 \\
\hline $0 \mathrm{~s}$ & - & - & 39.19 & 32.34 & 17.90 & 10.58 \\
$5 \mathrm{~s}$ & - & - & 46.17 & 37.94 & 10.90 & 4.99 \\
$15 \mathrm{~s}$ & - & - & 48.87 & 36.29 & 10.87 & 3.97 \\
$30 \mathrm{~s}$ & 3.72 & 4.38 & 39.16 & 28.52 & 14.39 & 9.82 \\
$60 \mathrm{~s}$ & 1.87 & 14.34 & 38.04 & 35.64 & 1.80 & 8.31 \\
$120 \mathrm{~s}$ & 22.66 & 28.72 & 20.46 & 15.21 & 2.69 & 10.26 \\
\hline
\end{tabular}

Table 2. Percentage of Sn species obtained from XPS analysis.

\begin{tabular}{ccccc}
\hline APPJ Sn3d (\%) & Sn 5/2 & Sn $\mathbf{3 / 2}$ & Sn(II/IV) 5/2 & Sn(II/IV) 3/2 \\
\hline $0 \mathrm{~s}$ & - & - & 60.19 & 39.81 \\
$5 \mathrm{~s}$ & 1.13 & 0.36 & 58.33 & 40.19 \\
$15 \mathrm{~s}$ & 2.21 & 1.31 & 56.95 & 39.53 \\
$30 \mathrm{~s}$ & 4.17 & 1.72 & 55.35 & 38.76 \\
$60 \mathrm{~s}$ & 3.72 & 1.14 & 56.27 & 38.87 \\
$120 \mathrm{~s}$ & 6.72 & 2.93 & 53.51 & 36.84 \\
\hline
\end{tabular}

Figure $5 \mathrm{a}, \mathrm{b}$ shows the EIS Nyquist and Bode phase plots to evaluate the catalytic activities of APPJ-processed Pt-SnO $x$ CEs. The inset of Figure 5a shows the equivalent circuit for Nyquist curve fitting [59]. The series resistance $\left(R_{\mathrm{s}}\right)$ and charge-transfer resistance $\left(R_{\mathrm{ct}}\right)$ can be described as the resistance of substrates and the catalytic effect of the electrode-reducing triiodide ions, respectively. $R_{\mathrm{s}}$ can be obtained from the high-frequency intercept on the real axis and $R_{\mathrm{ct}}$, from the radius of the real semi-circle [60]. Table 3 shows the EIS parameters including $R_{\mathrm{s}}, R_{\mathrm{ct}}$, and constant phase element (CPE1) [29]. A higher catalytic effect and lower charge-transfer resistance would improve the DSSC performance. For all cases, $R_{\mathrm{s}}$ of $\mathrm{Pt}-\mathrm{SnO}_{x}$ CEs remained similar. $R_{\mathrm{ct}}$ generally decreased (i.e., semi-circle became smaller) as the APPJ processing time increased, indicating that APPJ processing can enhance the catalytic activity. $R_{\mathrm{ct}}$ was comparable for APPJ processing times of $60 \mathrm{~s}(4.72 \Omega)$ and $120 \mathrm{~s}(4.69 \Omega)$. Lower $R_{\mathrm{ct}}$ results in a higher electrocatalytic activity at the interface between the CEs and the electrolytes [61]. CPE1, which represents the interfacial capacitance between the electrode and the electrolyte, is also a good indicator of the surface activity of CEs [62-64]. The $120 \mathrm{~s}$ APPJ-processed CEs had a higher CPE1-T $\left(105.5 \mu \mathrm{F} / \mathrm{cm}^{2}\right)$, indicating larger surface reaction between the $\mathrm{CE}$ and the electrolyte. Bode phase plots show the electron lifetime for recombination in devices; the electron lifetime is expressed as $\tau_{\mathrm{e}}=1 /\left(2 \pi f_{\text {peak }}\right)$, where $f_{\text {peak }}$ is the frequency of the highest peak. Shorter electron lifetime indicates faster charge transfer at the interface between the $\mathrm{CE}$ and the electrolyte [64,65]. In Figure 5b, the trend of the electron lifetime follows the EIS results. The $5 \mathrm{~s}$ APPJ-processed CE has the smallest peak frequency, indicating the largest electron lifetime with slower charge transfer. Furthermore, electron lifetimes are comparable in $60 \mathrm{~s}$ and $120 \mathrm{~s}$ APPJ-processed CEs, and this is consistent with the results for $R_{\mathrm{ct}}$.

To further clarify the catalytic activities of $\mathrm{Pt}_{-} \mathrm{SnO}_{x} \mathrm{CEs}$, Tafel polarization experiments were conducted and the results are shown in Figure 6 . The exchange current density $\left(J_{0}\right)$ was measured by the intercept of the Y-axis (zero voltage) from the tangential line of the curve [66,67]. The $120 \mathrm{~s}$ APPJ-processed CEs had a large $J_{0}$, indicating better electrocatalyic activity and lower charge-transfer resistance at the interface of the $\mathrm{CE}$ and the electrolyte. Table 3 shows that $J_{0}$ increases with the APPJ processing time. APPJ processes enhanced the triiodide reduction reaction [60]. The exchange current density is also proportional to $R_{\mathrm{ct}}$ obtained from the EIS measurement. It can be described as $J_{0}=R T / n F R_{\mathrm{ct}}$, where $R$ is a gas constant; $T$ is temperature; $n$ is the number of electrons involved in the redox reaction; and $F$ is the Faraday's constant [68]. EIS and Tafel measurements both indicate that APPJ-processed Pt-SnO $x$ elecrodes show suitable catalytic performance for use as the CEs of DSSCs. 
$J_{0}$ increases with the APPJ processing time, indicating that APPJ processing can enhance the catalyst activity of $\mathrm{Pt}-\mathrm{SnO}_{x}$.

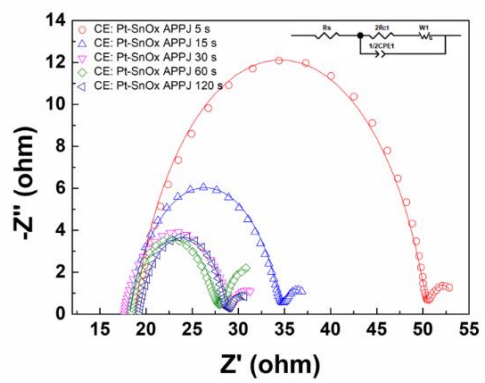

(a)

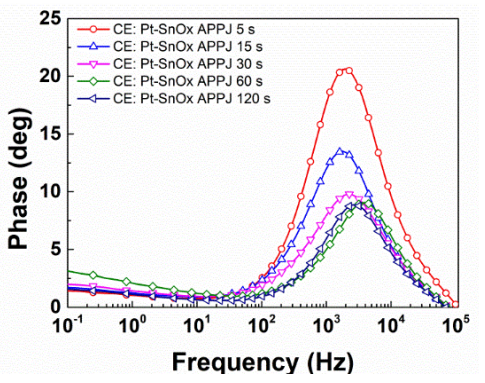

(b)

Figure 5. (a) Nyquist curves of symmetric cells with two $\mathrm{Pt}-\mathrm{SnO}_{x} \mathrm{CEs}$. The inset shows the equivalent circuit diagram. (b) Bode phase plots of symmetric cells with two $\mathrm{Pt}-\mathrm{SnO}_{x}$ CEs.

Table 3. EIS parameters of $\mathrm{Pt}_{-} \mathrm{SnO}_{x}$ CEs.

\begin{tabular}{|c|c|c|c|c|c|c|c|c|c|c|}
\hline \multirow{2}{*}{\multicolumn{2}{|c|}{$\begin{array}{l}\text { Counter } \\
\text { Electrode }\end{array}$}} & \multirow{2}{*}{$\begin{array}{l}R_{\mathrm{s}} \\
(\Omega)\end{array}$} & \multirow{2}{*}{$\begin{array}{l}R_{\mathrm{ct}} \\
(\Omega)\end{array}$} & \multirow{2}{*}{$\begin{array}{l}\text { CPE1-T } \\
\left(\mu \mathrm{F} / \mathrm{cm}^{2}\right)\end{array}$} & \multirow{2}{*}{ CPE1-P } & \multicolumn{3}{|c|}{ W1 } & \multirow{2}{*}{$\begin{array}{c}J_{0}^{a} \\
\left(\mathrm{~mA} / \mathrm{cm}^{2}\right)\end{array}$} & \multirow{2}{*}{$\begin{array}{c}J_{0}^{b} \\
\left(\mathrm{~mA} / \mathrm{cm}^{2}\right)\end{array}$} \\
\hline & & & & & & $\mathrm{W} 1-R(\Omega)$ & $\mathrm{W} 1-T(\mathrm{~s})$ & W1-P & & \\
\hline \multirow{5}{*}{$\begin{array}{c}\mathrm{Pt}-\mathrm{SnO}_{x} \\
\mathrm{APPJ}\end{array}$} & $5 \mathrm{~s}$ & 18.8 & 15.74 & 35.6 & 0.835 & 3.23 & 2.13 & 0.5 & 0.82 & 1.04 \\
\hline & $15 \mathrm{~s}$ & 18.2 & 8.18 & 83.1 & 0.808 & 2.82 & 1.99 & 0.5 & 1.58 & 1.39 \\
\hline & $30 \mathrm{~s}$ & 17.55 & 5.8 & 95 & 0.75 & 2.73 & 2.25 & 0.5 & 2.23 & 1.67 \\
\hline & $60 \mathrm{~s}$ & 18.25 & 4.72 & 105 & 0.815 & 5.04 & 3.15 & 0.5 & 2.74 & 1.85 \\
\hline & $120 \mathrm{~s}$ & 19.28 & 4.69 & 105.5 & 0.84 & 2.21 & 1.8 & 0.5 & 2.75 & 2.08 \\
\hline
\end{tabular}

${ }^{\mathrm{a}} J_{0}$ : Exchange current density is calculated from $R_{\mathrm{ct}} \cdot{ }^{\mathrm{b}} J_{0}$ : Exchange current density is calculated from Tafel curve.

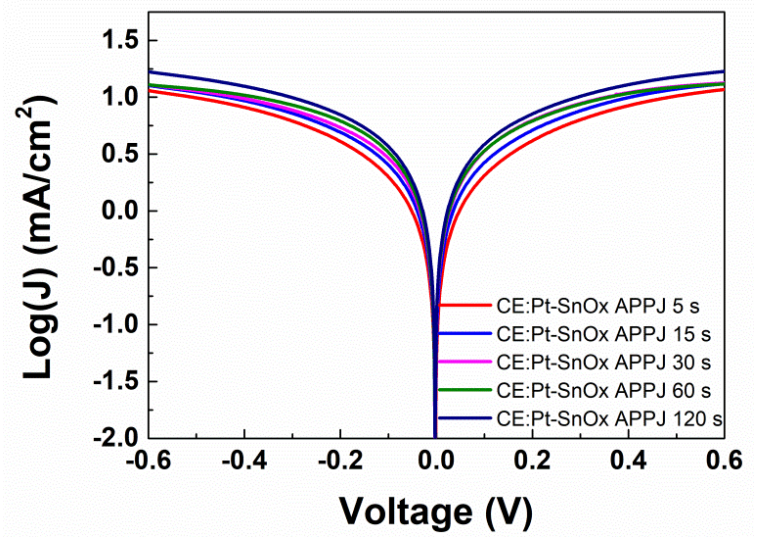

Figure 6. Tafel curves of symmetric cells with various $\mathrm{Pt}_{-} \mathrm{SnO}_{x} \mathrm{CEs}$.

Figure 7 shows the IV curves of DSSCs with APPJ-processed Pt-SnO $x_{x}$ CEs. Table 4 shows the photovoltaic parameters, including the open-circuit voltage $\left(V_{\mathrm{oc}}\right)$, short-circuit current $\left(J_{\mathrm{sc}}\right)$, fill factor (FF), and efficiency (EFF) with their standard deviations. The power conversion efficiencies (PCEs) of DSSCs with $5 \mathrm{~s}$ and $15 \mathrm{~s}$ APPJ-processed Pt-SnO $\mathrm{C}_{x}$ CEs are $3.87 \pm 0.58 \%$ and $3.86 \pm 0.28 \%$, respectively, indicating that APPJ processing for a short duration can improve the DSSC performance. XPS results show that almost no metallic Pt was converted with $5 \mathrm{~s}$ and $15 \mathrm{~s}$ APPJ processing, indicating the catalytic effect of oxidized Pt and Sn compound CEs in DSSCs, and this agrees with previous reported findings [30,32]. As the APPJ treatment time increases, the PCE of DSSCs with $30 \mathrm{~s}, 60 \mathrm{~s}$, and $120 \mathrm{~s}$ APPJ-processed CEs reaches $4.01 \pm 0.34 \%, 4.20 \pm 0.41 \%$, and $4.46 \pm 0.29 \%$, respectively. The performance of DSSC with a $120 \mathrm{~s}$ APPJ-processed $\mathrm{Pt}_{-} \mathrm{SnO}_{x} \mathrm{CE}$ was comparable to that with a 
conventional furnace-processed Pt CE (4.42 $\pm 0.26 \%)$. Figure 8 shows the statistics of the DSSC parameters. APPJ processing gradually increased the FFs and PCEs of DSSCs, consistent with the results obtained from EIS and Tafel measurement. The improved FF and efficiency with APPJ processing time could result from the better conversion of metallic Pt from the precursor solution.

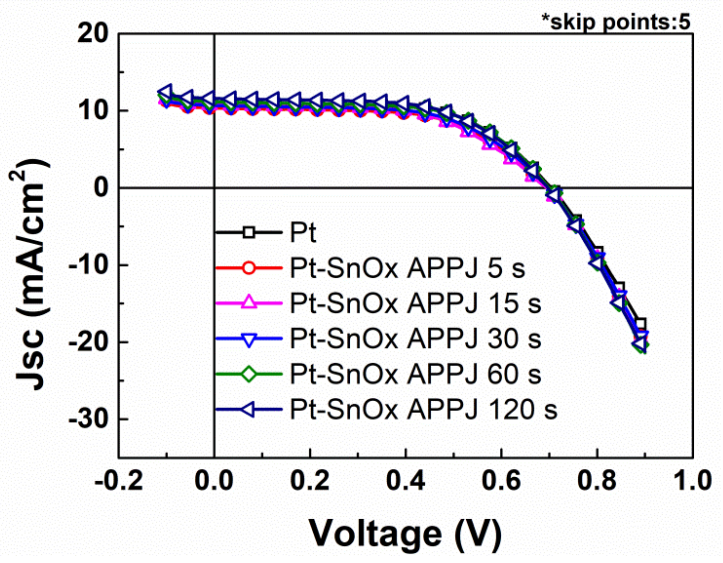

Figure 7. Photocurrent density-voltage curves of DSSCs with various CEs.

Table 4. Photovoltaic parameters of DSSCs with different CEs.

\begin{tabular}{cccccc}
\hline Condition & & $V_{\mathbf{o c}} \mathbf{( V )}$ & $J_{\mathbf{s c}}\left(\mathbf{m A} / \mathbf{c m}^{\mathbf{2}}\right)$ & FF (\%) & EFF (\%) \\
\hline $\mathrm{Pt}$ & & $0.70 \pm 0.02$ & $10.34 \pm 0.47$ & $61.27 \pm 1.91$ & $4.42 \pm 0.26$ \\
& $5 \mathrm{~s}$ & $0.70 \pm 0.01$ & $10.76 \pm 0.82$ & $51.65 \pm 6.03$ & $3.87 \pm 0.58$ \\
$\mathrm{Pt}^{2} \mathrm{SnO}_{x} \mathrm{APPJ}$ & $15 \mathrm{~s}$ & $0.69 \pm 0.02$ & $10.30 \pm 0.78$ & $54.43 \pm 2.65$ & $3.86 \pm 0.28$ \\
& $30 \mathrm{~s}$ & $0.69 \pm 0.02$ & $10.26 \pm 0.80$ & $56.38 \pm 2.37$ & $4.01 \pm 0.34$ \\
& $60 \mathrm{~s}$ & $0.69 \pm 0.02$ & $10.47 \pm 0.94$ & $57.91 \pm 2.04$ & $4.20 \pm 0.41$ \\
& $120 \mathrm{~s}$ & $0.70 \pm 0.02$ & $10.72 \pm 0.75$ & $59.41 \pm 1.08$ & $4.46 \pm 0.29$ \\
\hline
\end{tabular}
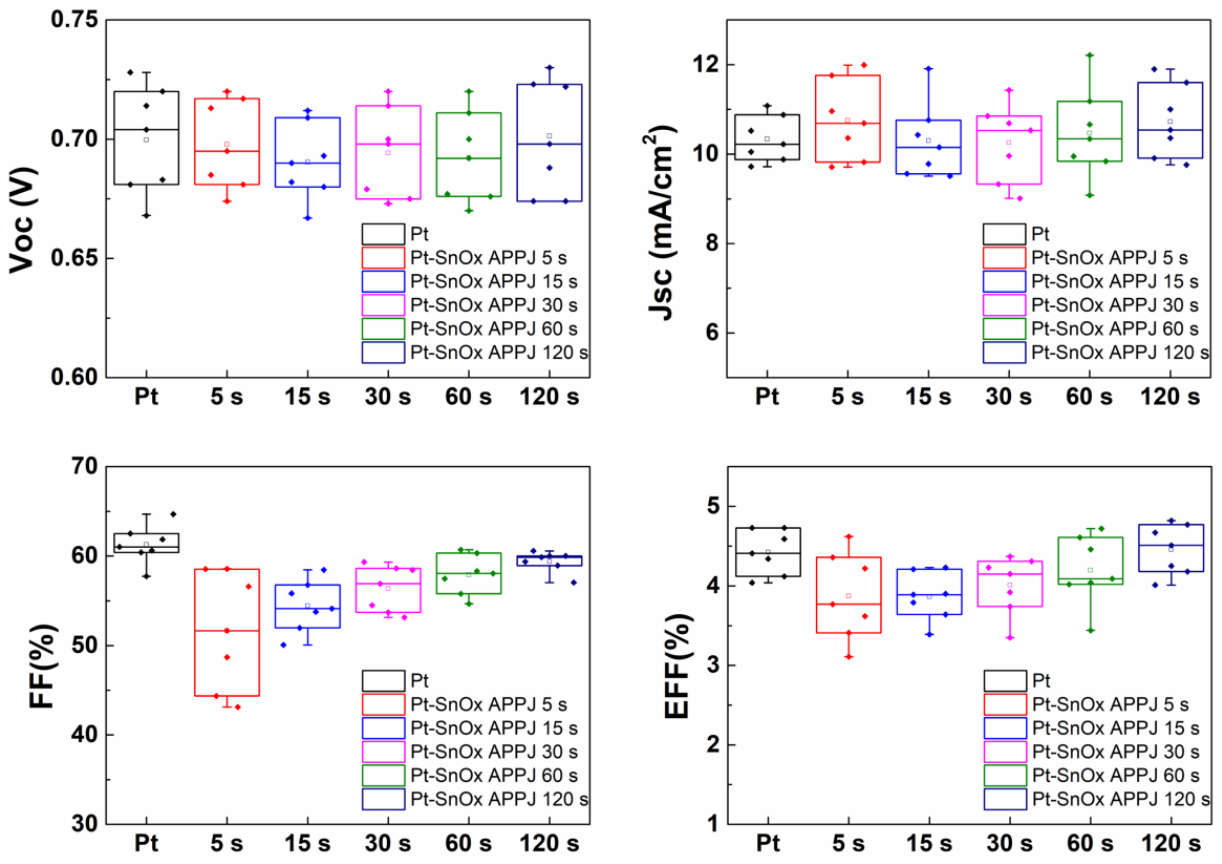

Figure 8. Statistics of DSSC parameters based on APPJ-processed Pt-SnO ${ }_{x}$ CEs and furnace-processed Pt CE (reference). 


\section{Conclusions}

We analyze the time evolution of $\mathrm{Pt}_{-} \mathrm{SnO}_{x}$ nanoparticle catalysts that are converted from a mixture of chloroplatinic acid and tin(II) chloride using DC-pulse nitrogen APPJ. XPS analyses indicate the conversion of a large portion of the metallic Pt and tin oxide. EIS and Tafel measurements indicate improved electrochemical catalytic effects. The synthesized $\mathrm{Pt}_{-} \mathrm{SnO}$. nanoparticles on FTO glass substrates are used as the CEs of DSSCs. The I-V curve shows that the performance of DSSCs with APPJ-processed Pt-SnO ${ }_{x}$ CEs is comparable to that of DSSCs with conventional furnace-processed Pt CEs. As the APPJ processing time is increased, the FF and efficiency of DSSCs gradually increase. Our results show that a DC-pulse nitrogen APPJ is an efficient tool for synthesizing Pt-SnO $\mathrm{x}_{\mathrm{x}}$ catalysts from a mixture precursor solution consisting of chloroplatinic acid and tin(II) chloride.

Author Contributions: C.-C.L. performed the experiments, analyzed the data, and wrote the paper draft. T.-M.H. assisted in conducting experiments. I.-C.C. and C.-C.H. assisted in instructing the research and analyzing the data. J.-Z.C. directed the research direction, analyzed the data, and revised the paper. All authors commented on the manuscript.

Funding: This work is supported by the "Advanced Research Center for Green Materials Science and Technology" from The Featured Area Research Center Program of the Higher Education Sprout Project by the Ministry of Education (107L9006) and the Ministry of Science and Technology in Taiwan (MOST 105-2221-E-002-047-MY3, MOST 106-2221-E-002-193-MY2 \& MOST 107-3017-F-002-001).

Acknowledgments: The cleanroom facility is provided by the Nano-Electro-Mechanical-Systems (NEMS) Research Center at National Taiwan University. Yuan-Tzu Lee of the Instrumentation Center at National Taiwan University helps with the SEM operation.

Conflicts of Interest: The authors declare no conflict of interest.

\section{References}

1. Schutze, A.; Jeong, J.Y.; Babayan, S.E.; Park, J.; Selwyn, G.S.; Hicks, R.F. The atmospheric-pressure plasma jet: A review and comparison to other plasma sources. IEEE Trans. Plasma Sci. 1998, 26, 1685-1694. [CrossRef]

2. Laroussi, M.; Akan, T. Arc-free atmospheric pressure cold plasma jets: A review. Plasma Proc. Polym. 2007, 4, 777-788. [CrossRef]

3. Chen, J.-Z.; Wang, C.; Hsu, C.-C.; Cheng, I.-C. Ultrafast synthesis of carbon-nanotube counter electrodes for dye-sensitized solar cells using an atmospheric-pressure plasma jet. Carbon 2016, 98, 34-40. [CrossRef]

4. Chou, C.-Y.; Chang, H.; Liu, H.-W.; Yang, Y.-J.; Hsu, C.-C.; Cheng, I.-C.; Chen, J.-Z. Atmospheric-pressure-plasma-jet processed nanoporous $\mathrm{TiO}_{2}$ photoanodes and $\mathrm{Pt}$ counter-electrodes for dye-sensitized solar cells. RSC Adv. 2015, 5, 45662-45667. [CrossRef]

5. Wan, T.-H.; Chiu, Y.-F.; Chen, C.-W.; Hsu, C.-C.; Cheng, I.; Chen, J.-Z. Atmospheric-pressure plasma jet processed $\mathrm{Pt}$-decorated reduced graphene oxides for counter-electrodes of dye-sensitized solar cells. Coatings 2016, 6, 44. [CrossRef]

6. Wu, T.J.; Chou, C.Y.; Hsu, C.M.; Hsu, C.C.; Chen, J.Z.; Cheng, I.C. Ultrafast synthesis of continuous Au thin films from chloroauric acid solution using an atmospheric pressure plasma jet. RSC Adv. 2015, 5, 99654-99657. [CrossRef]

7. Liu, L.; Ye, D.; Yu, Y.; Liu, L.; Wu, Y. Carbon-based flexible micro-supercapacitor fabrication via mask-free ambient micro-plasma-jet etching. Carbon 2017, 111, 121-127. [CrossRef]

8. Kuok, F.-H.; Kan, K.-Y.; Yu, I.-S.; Chen, C.-W.; Hsu, C.-C.; Cheng, I.-C. Application of atmospheric-pressure plasma jet processed carbon nanotubes to liquid and quasi-solid-state electrolyte supercapacitors. Appl. Surf. Sci. 2017, 425, 321-328. [CrossRef]

9. Yang, C.-H.; Kuok, F.-H.; Liao, C.-Y.; Wan, T.-H.; Chen, C.-W.; Hsu, C.-C.; Cheng, I.-C.; Chen, J.-Z. Flexible reduced graphene oxide supercapacitor fabricated using a nitrogen dc-pulse atmospheric-pressure plasma jet. Mater. Res. Express 2017, 4, 025504. [CrossRef]

10. Liu, H.W.; Liang, S.P.; Wu, T.J.; Chang, H.; Kao, P.K.; Hsu, C.C.; Chen, J.Z.; Chou, P.T.; Cheng, I.C. Rapid atmospheric pressure plasma jet processed reduced graphene oxide counter electrodes for dye-sensitized solar cells. ACS Appl. Mater. Interfaces 2014, 6, 15105-15112. [CrossRef] [PubMed] 
11. Kuok, F.H.; Liao, C.Y.; Wan, T.H.; Yeh, P.W.; Cheng, I.C.; Chen, J.Z. Atmospheric pressure plasma jet processed reduced graphene oxides for supercapacitor application. J. Alloys Compd. 2017, 692, 558-562. [CrossRef]

12. Chen, S.L.; Wang, S.; Wang, Y.B.; Guo, B.H.; Li, G.Q.; Chang, Z.S.; Zhang, G.J. Surface modification of epoxy resin using $\mathrm{He} / \mathrm{CF}_{4}$ atmospheric pressure plasma jet for flashover withstanding characteristics improvement in vacuum. Appl. Surf. Sci. 2017, 414, 107-113. [CrossRef]

13. Munoz, J.; Bravo, J.A.; Calzada, M.D. Aluminum metal surface cleaning and activation by atmospheric-pressure remote plasma. Appl. Surf. Sci. 2017, 407, 72-81. [CrossRef]

14. Tsai, J.-H.; Cheng, I.-C.; Hsu, C.-C.; Chen, J.-Z. Dc-pulse atmospheric-pressure plasma jet and dielectric barrier discharge surface treatments on fluorine-doped tin oxide for perovskite solar cell application. J. Phys. D: Appl. Phys. 2017, 51, 025502. [CrossRef]

15. Bose, A.C.; Shimizu, Y.; Mariotti, D.; Sasaki, T.; Terashima, K.; Koshizaki, N. Flow rate effect on the structure and morphology of molybdenum oxide nanoparticles deposited by atmospheric-pressure microplasma processing. Nanotechnology 2006, 17, 5976-5982. [CrossRef]

16. Babayan, S.; Jeong, J.; Schütze, A.; Tu, V.; Moravej, M.; Selwyn, G.; Hicks, R. Deposition of silicon dioxide films with a non-equilibrium atmospheric-pressure plasma jet. Plasma Sources Sci. Technol. 2001, 10, 573. [CrossRef]

17. Patel, J.; Nemcova, L.; Maguire, P.; Graham, W.G.; Mariotti, D. Synthesis of surfactant-free electrostatically stabilized gold nanoparticles by plasma-induced liquid chemistry. Nanotechnology 2013, 24, 245604. [CrossRef] [PubMed]

18. Lee, C.-C.; Wan, T.-H.; Hsu, C.-C.; Cheng, I.-C.; Chen, J.-Z. Atmospheric-pressure plasma jet processed $\mathrm{Pt} / \mathrm{ZnO}$ composites and its application as counter-electrodes for dye-sensitized solar cells. Appl. Surf. Sci. 2018, 436, 690-696. [CrossRef]

19. Malecki, S.; Gargul, K. Low-waste recycling of spent CuO-ZnO- $\mathrm{Al}_{2} \mathrm{O}_{3}$ catalysts. Metals 2018, 8, 177. [CrossRef]

20. Paiva, A.P. Recycling of palladium from spent catalysts using solvent extraction-some critical points. Metals 2017, 7, 505. [CrossRef]

21. Fujita, T.; Higuchi, K.; Yamamoto, Y.; Tokunaga, T.; Arai, S.; Abe, H. In-situ TEM study of a nanoporous $\mathrm{Ni}$-Co catalyst used for the dry reforming of methane. Metals 2017, 7, 406. [CrossRef]

22. Joo, S.H.; Shin, D.J.; Oh, C.H.; Wang, J.P.; Park, J.T.; Shin, S.M. Application of Co and Mn for a Co-Mn-Br or $\mathrm{Co}-\mathrm{Mn}-\mathrm{C}_{2} \mathrm{H}_{3} \mathrm{O}_{2}$ petroleum liquid catalyst from the cathode material of spent lithium ion batteries by a hydrometallurgical route. Metals 2017, 7, 439. [CrossRef]

23. Tai, M.C.; Gentle, A.; de Silva, K.S.B.; Arnold, M.D.; van der Lingen, E.; Cortie, M.B. Thermal stability of nanoporous raney gold catalyst. Metals 2015, 5, 1197-1211. [CrossRef]

24. Sabitu, S.T.; Goudy, A.J. Dehydrogenation kinetics and modeling studies of $\mathrm{MgH}_{2}$ enhanced by transition metal oxide catalysts using constant pressure thermodynamic driving forces. Metals 2012, 2, 219-228. [CrossRef]

25. Song, H.; Hu, F.Y.; Peng, Y.; Li, K.Z.; Bai, S.P.; Li, J.H. Non-thermal plasma catalysis for chlorobenzene removal over $\mathrm{CoMn} / \mathrm{TiO}_{2}$ and $\mathrm{CeMn} / \mathrm{TiO}_{2}$ : Synergistic effect of chemical catalysis and dielectric constant. Chem. Eng. J. 2018, 347, 447-454. [CrossRef]

26. O'regan, B.; Grfitzeli, M. A low-cost, high-efficiency solar cell based on dye-sensitized. Nature 1991, 353, 737-740. [CrossRef]

27. Lin, C.-Y.; Lin, J.-Y.; Wan, C.-C.; Wei, T.-C. High-performance and low platinum loading electrodeposited-Pt counter electrodes for dye-sensitized solar cells. Electrochim. Acta 2011, 56, 1941-1946. [CrossRef]

28. Bae, K.-H.; Park, E.; Dao, V.-D.; Choi, H.-S. PtZn nanoalloy counter electrodes as a new avenue for highly efficient dye-sensitized solar cells. J. Alloys Compd. 2017, 702, 449-457. [CrossRef]

29. Dao, V.D.; Nang, L.V.; Kim, E.T.; Lee, J.K.; Choi, H.S. Pt nanoparticles immobilized on CVD-grown graphene as a transparent counter electrode material for dye-sensitized solar cells. ChemSusChem 2013, 6, 1316-1319. [CrossRef] [PubMed]

30. Li, C.-T.; Chang, H.-Y.; Li, Y.-Y.; Huang, Y.-J.; Tsai, Y.-L.; Vittal, R.; Sheng, Y.-J.; Ho, K.-C. Electrocatalytic zinc composites as the efficient counter electrodes of dye-sensitized solar cells: Study on the electrochemical performances and density functional theory calculations. ACS Appl. Mater. Interfaces 2015, 7, 28254-28263. [CrossRef] [PubMed] 
31. Wan, J.; Fang, G.; Yin, H.; Liu, X.; Liu, D.; Zhao, M.; Ke, W.; Tao, H.; Tang, Z. Pt-Ni alloy nanoparticles as superior counter electrodes for dye-sensitized solar cells: Experimental and theoretical understanding. Adv. Mater. 2014, 26, 8101-8106. [CrossRef] [PubMed]

32. Wang, H.; Wei, W.; Hu, Y.H. Efficient ZnO-based counter electrodes for dye-sensitized solar cells. J. Mater. Chem. A 2013, 1, 6622-6628. [CrossRef]

33. Yang, Q.; Duan, J.; Yang, P.; Tang, Q. Counter electrodes from platinum alloy nanotube arrays with zno nanorod templates for dye-sensitized solar cells. Electrochim. Acta 2016, 190, 648-654. [CrossRef]

34. Tang, Q.; Duan, J.; Duan, Y.; He, B.; Yu, L. Recent advances in alloy counter electrodes for dye-sensitized solar cells. A critical review. Electrochim. Acta 2015, 178, 886-899. [CrossRef]

35. Nechiyil, D.; Vinayan, B.P.; Ramaprabhu, S. Tri-iodide reduction activity of ultra-small size ptfe nanoparticles supported nitrogen-doped graphene as counter electrode for dye-sensitized solar cell. J. Colloid Interface Sci. 2017, 488, 309-316. [CrossRef] [PubMed]

36. Jin, I.-K.; Dao, V.-D.; Larina, L.L.; Choi, H.-S. Optimum engineering of a PtSn alloys/reduced graphene oxide nanohybrid for a highly efficient counter electrode in dye-sensitized solar cells. J. Ind. Eng. Chem. 2016, 36, 238-244. [CrossRef]

37. Zhu, Y.J.; Gao, C.J.; Han, Q.J.; Wang, Z.; Wang, Y.R.; Zheng, H.K.; Wu, M.X. Large-scale high-efficiency dye-sensitized solar cells based on a $\mathrm{Pt} /$ carbon spheres composite catalyst as a flexible counter electrode. J. Catal. 2017, 346, 62-69. [CrossRef]

38. Jiang, L.; Sun, G.; Sun, S.; Liu, J.; Tang, S.; Li, H.; Zhou, B.; Xin, Q. Structure and chemical composition of supported Pt-Sn electrocatalysts for ethanol oxidation. Electrochim. Acta 2005, 50, 5384-5389. [CrossRef]

39. Baranova, E.A.; Padilla, M.A.; Halevi, B.; Amir, T.; Artyushkova, K.; Atanassov, P. Electrooxidation of ethanol on PtSn nanoparticles in alkaline solution: Correlation between structure and catalytic properties. Electrochim. Acta 2012, 80, 377-382. [CrossRef]

40. Pang, H.; Lu, J.; Chen, J.; Huang, C.; Liu, B.; Zhang, X. Preparation of $\mathrm{SnO}_{2}-\mathrm{CNTs}$ supported Pt catalysts and their electrocatalytic properties for ethanol oxidation. Electrochim. Acta 2009, 54, 2610-2615. [CrossRef]

41. Ordonez, L.C.; Roquero, P.; Sebastian, P.J.; Ramirez, J. Carbon-supported platinum-molybdenum electro-catlysts for methanol oxidation. Catal. Today 2005, 107, 46-52. [CrossRef]

42. Jiang, L.H.; Sun, G.Q.; Zhou, Z.H.; Xin, Q. Preparation and characterization of PtSn/C anode electrocatalysts for direct ethanol fuel cell. Catal. Today 2004, 93, 665-670. [CrossRef]

43. Jiang, W.; Pang, Y.J.; Gu, L.L.; Yao, Y.; Su, Q.; Ji, W.J.; Au, C.T. Structurally defined $\mathrm{SnO}_{2}$ substrates, nanostructured $\mathrm{Au} / \mathrm{SnO}_{2}$ interfaces, and their distinctive behavior in benzene and methanol oxidation. J. Catal. 2017, 349, 183-196. [CrossRef]

44. Lee, B.; Sakamoto, Y.; Hirabayashi, D.; Suzuki, K.; Hibino, T. Direct oxidation of methane to methanol over proton conductor/metal mixed catalysts. J. Catal. 2010, 271, 195-200. [CrossRef]

45. Xie, J.H.; Falcone, D.D.; Davis, R.J. Restructuring of supported PtSn bimetallic catalysts during aqueous phase oxidation of 1,6-hexanediol. J. Catal. 2015, 332, 38-50. [CrossRef]

46. Mädler, L.; Roessler, A.; Pratsinis, S.E.; Sahm, T.; Gurlo, A.; Barsan, N.; Weimar, U. Direct formation of highly porous gas-sensing films by in situ thermophoretic deposition of flame-made $\mathrm{Pt} / \mathrm{SnO}_{2}$ nanoparticles. Sens. Actuators B Chem. 2006, 114, 283-295. [CrossRef]

47. Antolini, E. Formation of carbon-supported PtM alloys for low temperature fuel cells: A review. Mater. Chem. Phys. 2003, 78, 563-573. [CrossRef]

48. Khelashvili, G.; Behrens, S.; Hinsch, A.; Habicht, W.; Schild, D.; Eichhöfer, A.; Sastrawan, R.; Skupien, K.; Dinjus, E.; Bönnemann, H. Preparation and characterization of low platinum loaded $\mathrm{Pt}: \mathrm{SnO}_{2}$ electrocatalytic films for screen printed dye solar cell counter electrode. Thin Solid Films 2007, 515, 4074-4079. [CrossRef]

49. Sun, H.; Ullah, R.; Chong, S.; Ang, H.M.; Tadé, M.O.; Wang, S. Room-light-induced indoor air purification using an efficient Pt/N-TiO 2 photocatalyst. Appl. Catal. B Environ. 2011, 108, 127-133. [CrossRef]

50. Ma, Y.; Wang, H.; Ji, S.; Linkov, V.; Wang, R. PtSn/C catalysts for ethanol oxidation: The effect of stabilizers on the morphology and particle distribution. J. Power Sources 2014, 247, 142-150. [CrossRef]

51. Xu, J.; Liu, X.; Chen, Y.; Zhou, Y.; Lu, T.; Tang, Y. Platinum-cobalt alloy networks for methanol oxidation electrocatalysis. J. Mater. Chem. 2012, 22, 23659-23667. [CrossRef]

52. Zhang, Y.; Han, T.; Zhu, L.; Fang, J.; Xu, J.; Xu, P.; Li, X.; Liu, C.-C. Pt35Cu65 nanoarchitecture: A highly durable and effective electrocatalyst towards methanol oxidation. Nanotechnology 2015, 26, 135706. [CrossRef] [PubMed] 
53. Silva, J.; De Souza, R.F.; Romano, M.A.; D’Villa-Silva, M.; Calegaro, M.L.; Hammer, P.; Neto, A.O.; Santos, M.C. PtSnIr/C anode electrocatalysts: Promoting effect in direct ethanol fuel cells. J. Braz. Chem. Soc. 2012, 23, 1146-1153. [CrossRef]

54. García-Rodríguez, S.; Somodi, F.; Borbáth, I.; Margitfalvi, J.L.; Peña, M.A.; Fierro, J.L.G.; Rojas, S. Controlled synthesis of Pt-Sn/C fuel cell catalysts with exclusive Sn-Pt interaction: Application in co and ethanol electrooxidation reactions. Appl. Catal. B Environ. 2009, 91, 83-91. [CrossRef]

55. De la Fuente, J.G.; Rojas, S.; Martínez-Huerta, M.; Terreros, P.; Pena, M.; Fierro, J. Functionalization of carbon support and its influence on the electrocatalytic behaviour of $\mathrm{Pt} / \mathrm{C}$ in $\mathrm{H}_{2}$ and Co electrooxidation. Carbon 2006, 44, 1919-1929. [CrossRef]

56. Vilella, I.; De Miguel, S.; Scelza, O. Hydrogenation of citral on Pt and PtSn supported on activated carbon felts (ACF). Latin Am. Appl. Res. 2005, 35, 51-57.

57. Vilella, I.M.; de Miguel, S.R.; de Lecea, C.S.-M.; Linares-Solano, Á.; Scelza, O.A. Catalytic performance in citral hydrogenation and characterization of PtSn catalysts supported on activated carbon felt and powder. Appl. Catal. A Gen. 2005, 281, 247-258. [CrossRef]

58. Crabb, E.M.; Marshall, R.; Thompsett, D. Carbon monoxide electro-oxidation properties of carbon-supported PtSn catalysts prepared using surface organometallic chemistry. J. Electrochem. Soc. 2000, 147, 4440-4447. [CrossRef]

59. Gong, F.; Wang, H.; Wang, Z.-S. Self-assembled monolayer of graphene/Pt as counter electrode for efficient dye-sensitized solar cell. Phys. Chem. Chem. Phys. 2011, 13, 17676-17682. [CrossRef] [PubMed]

60. Yue, G.; Wu, J.; Xiao, Y.; Lin, J.; Huang, M.; Lan, Z.; Fan, L. Functionalized graphene/poly (3, 4-ethylenedioxythiophene): Polystyrenesulfonate as counter electrode catalyst for dye-sensitized solar cells. Energy 2013, 54, 315-321. [CrossRef]

61. Yin, X.; Xue, Z.; Liu, B. Electrophoretic deposition of Pt nanoparticles on plastic substrates as counter electrode for flexible dye-sensitized solar cells. J. Power Sources 2011, 196, 2422-2426. [CrossRef]

62. Sigdel, S.; Dubey, A.; Elbohy, H.; Aboagye, A.; Galipeau, D.; Zhang, L.; Fong, H.; Qiao, Q. Dye-sensitized solar cells based on spray-coated carbon nanofiber $/ \mathrm{TiO}_{2}$ nanoparticle composite counter electrodes. J. Mater. Chem. A 2014, 2, 11448-11453. [CrossRef]

63. Wang, Q.; Moser, J.-E.; Grätzel, M. Electrochemical impedance spectroscopic analysis of dye-sensitized solar cells. J. Phys. Chem. B 2005, 109, 14945-14953. [CrossRef] [PubMed]

64. Agarwala, S.; Thummalakunta, L.; Cook, C.; Peh, C.; Wong, A.; Ke, L.; Ho, G. Co-existence of LiI and KI in filler-free, quasi-solid-state electrolyte for efficient and stable dye-sensitized solar cell. J. Power Sources 2011, 196, 1651-1656. [CrossRef]

65. Jeong, H.; Pak, Y.; Hwang, Y.; Song, H.; Lee, K.H.; Ko, H.C.; Jung, G.Y. Enhancing the charge transfer of the counter electrode in dye-sensitized solar cells using periodically aligned platinum nanocups. Small 2012, 8 , 3757-3761. [CrossRef] [PubMed]

66. Park, K.-H.; Kim, S.J.; Gomes, R.; Bhaumik, A. High performance dye-sensitized solar cell by using porous polyaniline nanotubes as counter electrode. Chem. Eng. J. 2015, 260, 393-398. [CrossRef]

67. Yue, G.; Wu, J.; Xiao, Y.; Huang, M.; Lin, J.; Lin, J.-Y. High performance platinum-free counter electrode of molybdenum sulfide-carbon used in dye-sensitized solar cells. J. Mater. Chem. A 2013, 1, 1495-1501. [CrossRef]

68. Zheng, X.J.; Guo, J.H.; Shi, Y.T.; Xiong, F.Q.; Zhang, W.H.; Ma, T.L.; Li, C. Low-cost and high-performance $\mathrm{CoMoS}_{4}$ and $\mathrm{NiMoS}_{4}$ counter electrodes for dye-sensitized solar cells. Chem. Commun. 2013, 49, 9645-9647. [CrossRef] [PubMed]

(C) 2018 by the authors. Licensee MDPI, Basel, Switzerland. This article is an open access article distributed under the terms and conditions of the Creative Commons Attribution (CC BY) license (http://creativecommons.org/licenses/by/4.0/). 